\title{
Growth forms and life-history strategies predict the occurrence of aquatic macrophytes in relation to environmental factors in a shallow peat lake complex
}

\author{
Ralph J. M. Temmink (i) - Martijn Dorenbosch • Leon P. M. Lamers • \\ Alfons J. P. Smolders • Winnie Rip • Wouter Lengkeek • Karin Didderen • \\ Gregory S. Fivash $\cdot$ Tjeerd J. Bouma $\cdot$ Tjisse van der Heide
}

Received: 8 February 2021 / Revised: 10 May 2021/Accepted: 16 May 2021/Published online: 27 May 2021

(C) The Author(s) 2021

\begin{abstract}
Aquatic ecosystems provide vital services, and macrophytes play a critical role in their functioning. Conceptual models indicate that in shallow lakes, plants with different growth strategies are expected to inhabit contrasting habitats. For shallow peat lakes, characterized by incohesive sediments, roles of growth forms, life-history strategies and environmental factors in determining the occurrence of aquatic vegetation remain unknown. In a field survey, we sampled 64 points in a peat lake complex and related
\end{abstract}

Handling editor: André Padial

Electronic supplementary material The online version of this article (https://doi.org/10.1007/s10750-021-04618-6) contains supplementary material, which is available to authorized users.

R. J. M. Temmink $(\bowtie) \cdot$ L. P. M. Lamers ·

A. J. P. Smolders - W. Lengkeek - T. van der Heide Aquatic Ecology and Environmental Biology, Institute for Water and Wetland Research, Radboud University,

Heyendaalseweg 135, 6525 AJ Nijmegen, the Netherlands e-mail: R.temmink@science.ru.nl

R. J. M. Temmink - T. van der Heide

Department Coastal Systems, Royal Netherlands Institute of Sea Research and Utrecht University,

1790 AB Den Burg, the Netherlands

M. Dorenbosch · W. Lengkeek · K. Didderen

Bureau Waardenburg, Varkensmarkt 9,

4101 CK Culemborg, The Netherlands macrophyte occurrence to growth forms (floatingleaved rooted and submerged), life-history strategies for overwintering (turions, seeds, rhizomes) and environmental factors (water depth, fetch, and porewater nutrients). Our survey showed that macrophyte occurrence relates to water depth, wind-fetch, and nutrients, and depends on growth form and life-history strategies. Specifically, rooted floating-leaved macrophytes occur at lower wind-fetch/shallower waters. Submerged macrophytes occur from low to greater wind-fetch/water depth, depending on life-history strategies; macrophytes with rhizomes occur at greater wind-fetch/depth relative to species that overwinter with seeds or turions. We conclude that growth form and life-history strategies for overwintering predict macrophytes occurrence regarding environmental

M. Dorenbosch

RAVON Nijmegen, Toernooiveld 1, 6525 ED Nijmegen, The Netherlands

L. P. M. Lamers · A. J. P. Smolders B-WARE Research Centre, Toernooiveld 1, 6525 ED Nijmegen, The Netherlands

W. Rip

Waternet, Amsterdam, Korte Ouderkerkerdijk 7, 1096 AC Amsterdam, The Netherlands

G. S. Fivash · T. J. Bouma

Department of Estuarine and Delta Systems, Royal Netherlands Institute of Sea Research and Utrecht University, 4401 NT Yerseke, The Netherlands 
factors in peat lakes. Therefore, we propose an adapted model for macrophyte occurrence for such lakes. Altogether, these results may aid in species-selection to revegetate peat lakes depending on its environment.

Keywords Floating-leaved rooted macrophytes . Submerged macrophytes - Vegetation · Nutrients · Fetch · Water depth

\section{Introduction}

Aquatic ecosystems provide a large range of ecological and economic services, including freshwater supply, fisheries, habitats and food for organisms driving biodiversity (Hammer \& Bastian, 1989; Jackson et al., 2001; Borst et al., 2018). The occurrence and abundance of aquatic macrophytes, determined by abiotic and biotic drivers, strongly influence these services (Bornette \& Puijalon, 2011; Bakker et al., 2013). Abiotic conditions that determine macrophyte occurrence and abundance include water transparency (i.e., light availability), carbon, nitrogen and phosphorus availability in surface water and sediment, water movement and soil phytotoxicity (Søndergaard et al., 2003; Lamers et al., 2013; Verhofstad et al., 2017). Biotic drivers of plant occurrence, abundance and growth include herbivory and bioturbation by water birds, large fish and crayfish (Gulati \& van Donk, 2002; Bakker et al., 2013; Bakker et al., 2016).

Aquatic macrophytes occur in a range of freshwater lakes that differ considerably in depth and surface area (Lehner \& Döll, 2004; Murphy et al., 2019). In shallow lakes, typically less than $3 \mathrm{~m}$ deep, the effect of sediment-water interactions is relatively large

\section{T. J. Bouma}

Delta Academy Applied Research Centre, HZ University of Applied Sciences, Postbus 364, 4380 AJ Vlissingen, The Netherlands

T. J. Bouma $\cdot$ T. van der Heide Faculty of Geosciences, Department of Physical Geography, Utrecht University, 3508 TC Utrecht, the Netherlands

\section{T. J. Bouma}

Conservation Ecology Group, Groningen Institute for Evolutionary Life Sciences, University of Groningen, 9700 CC Groningen, the Netherlands
(Scheffer, 1997; Bakker et al., 2013). In addition, submerged macrophytes can fill up the entire water column. As a consequence, they increase their competitive advantage over algae by lowering nutrient levels and providing shelter for algae-grazing zooplankton and piscivorous fish feeding on bioturbating and zooplankton- eating fish (Scheffer et al., 2001; Scheffer et al., 2003; Smolders et al., 2006).

Within these shallow lake systems, shallow peat lakes form a specific type. They can be natural or human-made, created by the extraction of peat in combination with erosion of surrounding peatlands (Gulati \& van Donk, 2002; Immers et al., 2015). The bottom of these lakes is characterized by very soft, organic sediment that forms a non-cohesive sludge layer (Schutten et al., 2005). Peat lakes therefore have different environmental dynamics compared to for instance sandy-sediment lakes (Bengtsson \& Hellström, 1992; Schutten et al., 2005). Because of their soft sediments, peat lakes are much more prone to wind-induced sediment resuspension that negatively affects water clarity (Bengtsson \& Hellström, 1992). Furthermore, the non-cohesive structure of the sediment may easily lead to macrophyte uprooting (Schutten et al., 2005). These factors may negatively influence macrophytes occurrence. Bornette \& Puijalon (2009) proposed a broadly applicable conceptual model in which they show the expected distribution of five major growth forms along several gradients of several abiotic factors (water transparency, seasonal temperature fluctuations, oxygen availability, substrate grain-size, nutrient level and water movement). For instance, they expected the occurrence of small caulescents (e.g., Elodea sp., Ceratophyllum demersum L.) at locations with higher water movement, while tall caulescents (e.g., Potamogeton lucens L.) and rooted floating-leaved macrophytes (Nymphaea sp.) are expected at conditions with lower water movement. They further expected the opposite relationship for nutrient levels for these species. Although they created this model to gain insight into the expected distribution of major macrophyte growth forms in shallow waters, the model was not specifically devised for shallow lakes with thick and noncohesive sediments, such as peat lakes. Therefore, it remains unknown whether the conceptualized relationships for different macrophyte growth forms holds true for peat lakes. 
In shallow peat lakes, we observed large-scale uprooting of aquatic macrophytes after several storms from late summer until winter. This indicates that local survival of aquatic macrophytes can be challenging, probably due to the combination of incohesive sediment and storms (Schutten et al., 2005; Łoboda et al., 2018). Therefore, we hypothesize that the occurrence of macrophytes is not only dependent on growth form and abiotic conditions (Bornette \& Puijalon, 2009), but that life-history strategies for overwintering (via seeds, turions or rhizomes) of aquatic macrophytes play an important role in determining their occurrence in peat lakes with unstable sediments. Next to our observation of uprooting, Schutten et al. (2005) showed that peat lakes have a low sediment cohesion relative to lakes with a sand soil. Moreover, they found that plants uproot more easily in sediments with a low sediment cohesion. While some species invest a large part of their energy in subsurface overwintering parts such as rhizomes that also increase anchoring strength, others occur as annuals and produce aboveground reproductive parts such as seeds or turions (Wiegleb et al., 1991; Song et al., 2017). The effectiveness of these life-history strategies depends on environmental conditions, successional stage and hydroperiod. For instance, heavy seeds require firm sediment for germination, because these will sink to depths where they are unable to germinate in non-cohesive sediments (Barrat-Segretain, 1996). Yet, to our knowledge, there are no studies that address the occurrence of aquatic macrophytes in shallow peat lakes and link that to growth form, life-history traits for overwintering and environmental conditions.

In this study, to fill these knowledge gaps for shallow peat lakes, we relate the occurrence of rooted floating-leaved, and submerged vegetation to environmental factors, growth forms and life-history strategies for overwintering. We performed a field survey to relate macrophyte growth form and life-history strategies for overwintering (via seeds, turions or rhizomes) to environmental variables such as fetch, water depth (proxy for light availability) and nutrient availability in a peat lake complex (Stichts Ankeveense Plassen) in the Netherlands. We chose to study these traits, as plants can easily uproot in the incohesive sediments in shallow peat lakes (Schutten et al., 2005) during storms that most frequently occur from late summer to early spring in the Netherlands (The Royal Netherlands Meteorological Institute, KNMI). We hypothesized that submerged and rooted floatingleaved macrophyte occurrence under certain environmental conditions (e.g., water depth and fetch) is driven by their growth forms combined with their lifehistory strategies for overwintering.

\section{Materials and methods}

Study site

Stichts Ankeveense Plassen (SAP) is a complex of connected shallow peat lakes situated in an extensive peat region in the provinces of Holland and Utrecht in the Netherlands $\left(52^{\circ} 16^{\prime} 15.78^{\prime \prime} \mathrm{N}, 5^{\circ} 4^{\prime} 49.15^{\prime \prime} \mathrm{E}\right.$, Fig. 1). The area was exploited for its peat in the 1800 s, which created a characteristic landscape of peat ponds ('petgaten' in Dutch; pits from which peat was extracted by dredging) and 'baulks' (land to dry dredged peat) (Zeeuw, 1978). Over a century, waveinduced erosion and enhanced organic matter degradation due to external eutrophication led to the formation of a complex of connected lakes of $>$ 80 ha with lakebeds of thick layer of organic, noncohesive sludge (1.26 [1.3] $\pm 0.5 \mathrm{~m}$, average [median] $\pm \mathrm{SD}$, lake open water in the survey $\sim 60$ ha, Fig. 1b). Over the last 30 years, water quality and related clarity have improved by mitigation measures in a number of lakes in the Netherlands including SAP, and have become sufficient to support the growth of submerged macrophytes (Dorenbosch et al., 2017; Fraters et al., 2017). Specifically, the relatively stable and average light extinction from 2012 to 2016 was $1.9 \mathrm{~m}$ (min: 1.3, max: 2.7, $\mathrm{n}=58$; data from Dorenbosch et al., 2017). Furthermore, the availability of both carbon dioxide $\left(\mathrm{CO}_{2}\right)\left(40 \mu \mathrm{mol} \mathrm{L}{ }^{-1}\right)$ and bicarbonate $\left(\mathrm{HCO}_{3}^{-}\right)$ $\left(1 \mathrm{mmol} \mathrm{L}^{-1}\right)$ in the water layer is relatively low at our study site (Dorenbosch et al., 2017). As there is low recreation pressure in SAP, physical disturbances caused by recreation, mowing of the vegetation and sediment resuspension by boat propellers are negligible, unlike in many other peat lakes.

\section{Survey}

To study the occurrence of rooted floating-leaved and submerged vegetation in SAP, we generated 64 random points - sampling stations - inside our study area using QGIS that were sampled in July 2018 
(a)

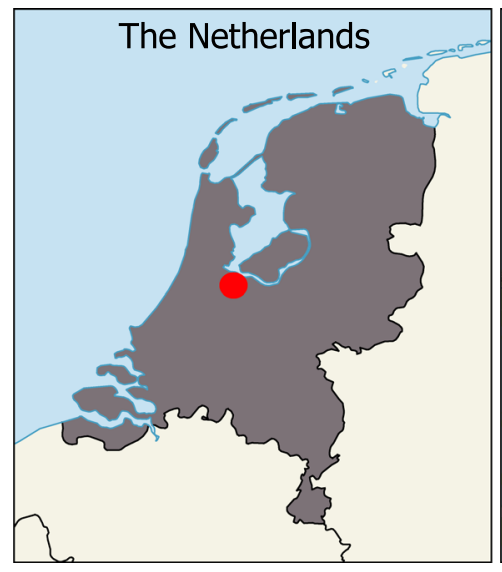

(b)

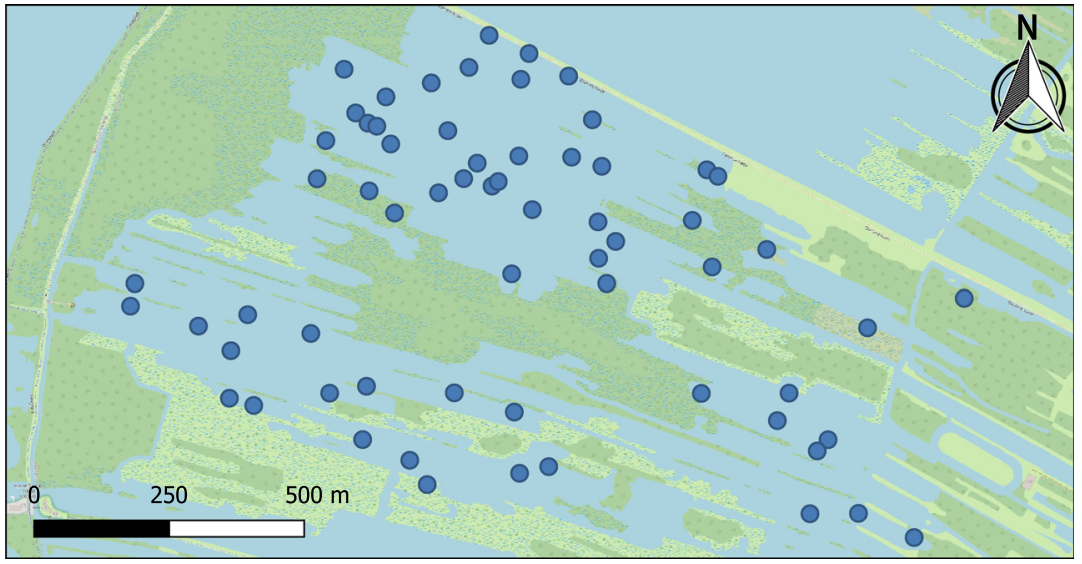

Fig. 1 Study site and experimental setup. (a) The Netherlands with the shallow peat lake complex Stichts Ankeveense Plassen (SAP) indicated by the red circle. (b) Detail of the study site.

(Fig. 1b). At each sampling station we visually, either by aquascope or eye, determined the total cover of rooted floating-leaved and submerged vegetation (\%) and relative abundance per species $(\%)$ for a given sampling area of approximately $4 \mathrm{~m}^{2}$. To account for possible species present underneath the highly dominant vegetation, we additionally used a rake connected to a rope to sample the vegetation $(34.5 \mathrm{~cm}$ wide rake with $6.5 \mathrm{~cm}$ long teeth spaced $2.5 \mathrm{~cm}$ apart). We threw the rake four times, once at each corner of the boat, and dragged it one meter across the sediment. If visibility was too low for visual cover estimation, we estimated the cover using the rake (Verhofstad et al., 2017).

Next, we measured water and sludge depth using a stainless steel grid attached to a marked pole (sediment level stave, Eijkelkamp, Giesbeek, the Netherlands). First, the grid rests on the sludge to measure the water level, then the grid is pushed until the hard mineral/peat subsoil, thus measuring the sludge depth. After this, we took a $30 \mathrm{~cm}$ deep sediment core of undisturbed and unvegetated sediment using a piston sampler (100 cm long; $4 \mathrm{~cm}$ in diameter, Eijkelkamp, Giesbeek, the Netherlands). Sediment concentrations of sulfide were low everywhere, based on the absence of its odor in the sediment (i.e., below 0.3-4 $\mu \mathrm{mol} 1^{-1}$; (National Research Council Committee, 2010). Finally, we stored each sample in an airtight plastic bag, and transported it to the lab, where it was stored at $4{ }^{\circ} \mathrm{C}$ overnight.
Blue circles indicate sampling stations in our field survey. Map data made with Natural Earth (a) and OpenStreetMap contributors, CC BY-SA (b)

We grouped all aquatic macrophyte species based on growth form: 1) rooted floating-leaved, and 2) submerged macrophytes (we observed no free-floating and emergent macrophytes in our survey), and lifehistory strategies related to overwintering 1) turions/ winter buds, 2) rhizome or 3) seeds (Table 1). We chose to correlate occurrence to overwintering strategies, because plants are prone to uprooting in unstable sediments during storm events (Schutten et al., 2005), which depends, on among others, on their overwintering root systems. Moreover, plants have different life-history strategies to cope with the cold conditions in winter (daily average temperature in winter $5.2^{\circ} \mathrm{C}$ [minimum $-8.5^{\circ} \mathrm{C}$ ] and summer: $18.9^{\circ} \mathrm{C}$ 2018 [maximum $37.5^{\circ} \mathrm{C}$ ]; KNMI weather station de Bilt, the Netherlands). Obviously, many plants produce seeds for reproduction; however, in our study lake in the Netherlands, plants that overwinter follow mainly the depicted classification (Table 1).

\section{Chemical analyses}

Sediments were carefully mixed in closed bags, after which porewater was extracted in the dark by inserting a rhizon sampler (Rhizon SMS, Rhizosphere Research Products B.V., Wageningen, the Netherlands) through the plastic, attached to a vacuumed syringe. We focused on the major nutrients for plant growth, namely, nitrogen, phosphorus and potassium. A 10 -mL subsample of each sample was conserved by 
Table 1 Groups of aquatic macrophyte species, growth form and life-history strategies for each found species including numbers of observations

\begin{tabular}{lllll}
\hline Submerged & & & Floating-leaved \\
\hline Free-floating & Rooted & Rhizome & \\
\cline { 2 - 5 } Turions/winter buds & Seeds & Myriophyllum spicatum $(\mathrm{n}=1)$ & Nymphaea alba $(\mathrm{n}=18)$ \\
\hline Elodea nuttallii $(\mathrm{n}=1)^{*}$ & Najas marina $(\mathrm{n}=12)$ & Potamogeton lucens $(\mathrm{n}=23)$ & Nuphar lutea $(\mathrm{n}=8)$ \\
Ceratophyllum demersum $(\mathrm{n}=9)$ & & P. crispus $\mathrm{L} . \mathrm{n}=1)$ & \\
& & P. perfoliatus $\mathrm{L} .(\mathrm{n}=3)$ & \\
\hline
\end{tabular}

*is not free-floating

adding $0.1 \mathrm{~mL}$ of nitric acid $\left(\mathrm{HNO}_{3}\right)(65 \%)$ and stored at $4{ }^{\circ} \mathrm{C}$ until $\mathrm{P}$-analysis by inductively coupled plasma emission spectrophotometry (ICP-OES iCAP 6000; Thermo Fisher Scientific, Waltham, MA, USA). The rest of each sample was stored in polyethylene bottles at $-20{ }^{\circ} \mathrm{C}$ prior to further analysis. Ammonium $\left(\mathrm{NH}_{4}{ }^{+}\right)$was measured colorimetrically with an auto analyzer (Auto Analyzer III, Bran and Luebbe GmbH, Norderstedt, Germany). Potassium $\left(\mathrm{K}^{+}\right)$was determined by flame photometry (FLM3Flame Photometer, Radiometer, Copenhagen, Denmark). Within one day after sampling, $\mathrm{pH}$ and alkalinity of the porewater were determined using an $\mathrm{Ag} / \mathrm{AgCl}$ electrode (Orion Research, Beverly, MA, USA) and a TIM 840 Titration Manager (Radiometer Analytical SAS, Villeurbanne, France). Total inorganic carbon (TIC $\mathrm{HCO}_{3}{ }^{-}$and $\mathrm{CO}_{2}$ ) was measured using an infrared carbon analyser (IRGA; ABB Analytical, Frankfurt, Germany), followed by $\mathrm{pH}$-based calculation of $\mathrm{CO}_{2}$ and $\mathrm{HCO}_{3}$ - concentrations (van Bergen et al., 2020). Finally, at each sampling station, we determined the fetch as the maximum distance from the sampling station toward the land in north, north-east, east, southeast, south, south-west, west and north-west direction with Google Earth Pro.

\section{Statistical analyses}

For the survey data, we used ANOVAs to test for differences between groups and environmental parameters. Macrophytes were categorized in groups based on growth form (rooted floating-leaved and submerged) and life-history trait-categories. This resulted in four groups, namely, (1) rooted floating-leaved (seed/rhizome), (2) submerged \& seed, (3) submerged
$\&$ turion and (4) submerged \& rhizome. For, the rooted floating-leaved group, we did not distinguish between seed and rhizome, as the two species that we found are both able to overwinter with seeds and rhizomes. Specifically, we tested whether differences occurred between these groups for water depth $\left(3^{\text {rd }}\right.$ root transformed), southwestern fetch (square root transformed, prevailing wind direction in the Netherlands, Supplementary Fig. S1), porewater P (square root transformed), $\mathrm{K}_{\text {and }} \mathrm{NH}_{4}{ }^{+}$concentrations (square root transformed). If necessary, variables were transformed to achieve a normal distribution of the residuals. Differences between groups were determined using Tukey post hoc tests. To prevent a large influence of a few individuals, sampling stations with a cover $>5 \%$ were only used for the analyses. Relationships between environmental parameters were explored using regression analyses between sludge depth and $\mathrm{NH}_{4}{ }^{+}, \mathrm{P}, \mathrm{HCO}_{3}^{-}$or alkalinity, and the southwestern fetch and sludge depth. All analyses were performed in $\mathrm{R}$ (version 3.6) statistical and programming environment (R Core Team, 2020). All results are shown with average, median and standard deviation $( \pm \mathrm{SD})$. The significance level was assumed at $p<0.05$.

\section{Results}

In our shallow peat lake complex, thickness of the sludge layer was negatively related to the southwestern fetch $\left(\mathrm{R}^{2}=0.3, p<0.001\right)$, while sediment and porewater nutrient concentrations in turn were positively related to sludge thickness $\left(\mathrm{R}^{2}=0.3,0,3,0,5\right.$ and 0.6 for porewater $\mathrm{NH}_{4}{ }^{+}, \mathrm{P}, \mathrm{HCO}_{3}^{-}$and alkalinity, respectively, $p<0.001$ for all, Fig. 2). The spatial 
Fig. 2 Abiotic relationships. Relationships between porewater ammonium $\left(\mu \mathrm{mol} \mathrm{L} \mathrm{L}^{-1}, \mathrm{a}\right)$, phosphorus $\left(\mu \mathrm{mol} \mathrm{L}{ }^{-1}, b\right)$ bicarbonate $\left(\mu \mathrm{mol} \mathrm{L}{ }^{-1}, \mathrm{c}\right)$ and alkalinity (meq $\mathrm{L}^{-1}, \mathrm{~d}$ ) and sludge depth $(\mathrm{cm})$. (e) shows the relationship between sludge depth and the southwestern fetch (m). Regression line is depicted in green. Black dots show individual data points (a)

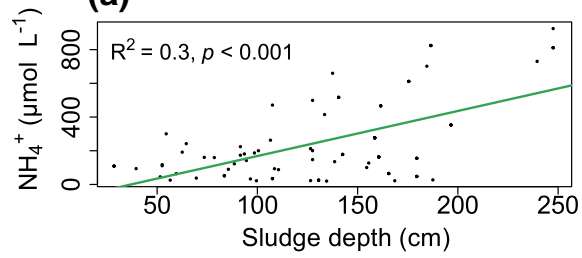

(c)

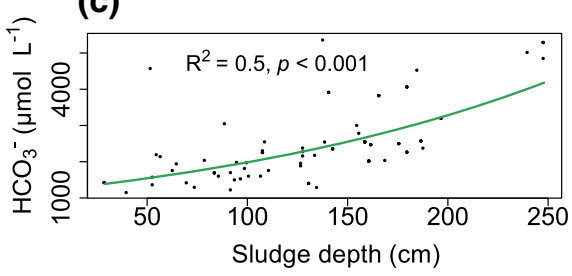

(e)

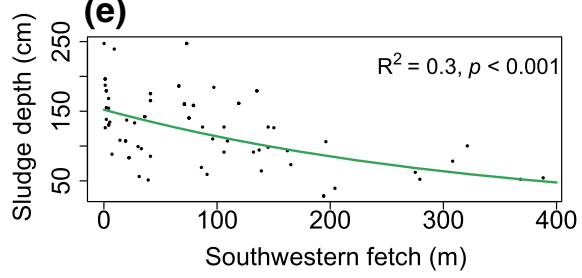

(b)

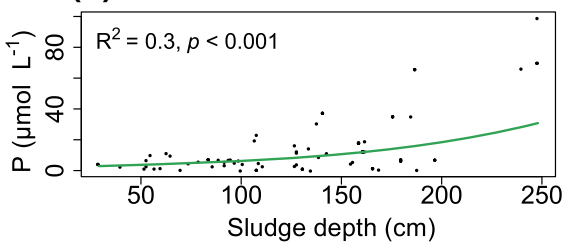

(d)

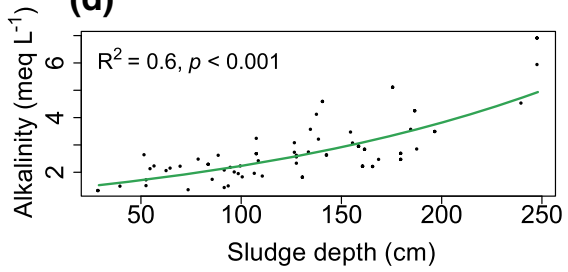

distribution of aquatic macrophytes was found to strongly depend on macrophyte growth form and lifehistory traits in relation to water depth, fetch and porewater nutrients concentrations (Fig. 3, 4).

In the shallow zone of the lake $(40-100 \mathrm{~cm})$ with a corresponding low SW fetch $(<100 \mathrm{~m}$, Fig. 3), we found the rooted floating-leaved macrophytes Nuphar lutea (L.) Sm. and Nymphaea alba L. (rhizome/seed) and the submerged macrophyte Najas marina L. (seed). At an intermediate depth (100 to $140 \mathrm{~cm}$ ) with a corresponding SW fetch of $180 \mathrm{~m}$ (Fig. 3), we found the rooted floating-leaved macrophytes $N$. lutea and $N$. $a l b a$, as well as various species of submerged macrophytes, including $N$. marina (seed), C. demersum (free-floating) and Elodea nuttallii (Planch.) St. John (turions), Myriophyllum spicatum L. (rhizome) and $P$. lucens (rhizome). At the deepest zone of the lake, from 140 to $180 \mathrm{~cm}$ depth with a corresponding SW fetch of at maximum $400 \mathrm{~m}$, only submerged macrophytes with rhizomes occurred (P. lucens, Fig. 3).

Specifically, we found the rooted floating-leaved vegetation to occur at water depths from 54 to $130 \mathrm{~cm}$ (97 [95] $\pm 21 \mathrm{~cm}$; average [median] \pm SD) and submerged vegetation from 45 to $177 \mathrm{~cm}$ (average $135[145] \pm 36 \mathrm{~cm})$. Within the submerged vegetation group, macrophytes having rhizomes or turions occurred at depths greater than $120 \mathrm{~cm}$ (average 155 [164] \pm 24 and 123 [127] $\pm 27 \mathrm{~cm}$, for macrophytes with rhizomes or turions respectively), while macrophytes that overwinter with seeds showed a great variation in water depth from 45 to $177 \mathrm{~cm}$ (average $\left.97[86] \pm 34 \mathrm{~cm}, \mathrm{~F}_{3,72}=27.26, \underline{p}<0.001\right)$. The recorded water depth was strongly related to the southwestern (SW) fetch - the predominant wind direction in the Netherlands $\left(\mathrm{R}^{2}=0.7, p<0.001\right.$, Fig. 3c).

Rooted floating-leaved vegetation occurred when SW fetch was less than $100 \mathrm{~m}$ (average 26 [18] \pm $28 \mathrm{~m}$ ). In contrast, SW fetch did not affect the occurrence of submerged macrophytes that have rhizomes, as indicated by the large range from 8 to $389 \mathrm{~m}$ (average $167[143] \pm 99 \mathrm{~m}, \mathrm{~F}_{3,72}=28.65, p<$ 0.001). However, SW fetch strongly affected the occurrence of submerged macrophytes that overwinter via seeds or turions (average 48 [40] \pm 43 and 83 [75] $\pm 28 \mathrm{~m}$ for seeds or turions, respectively).

Rooted floating-leaved vegetation occurred at sediment porewater concentrations lower than $12 \mu \mathrm{mol} P$ $\mathrm{L}^{-1}$ (average $4[3] \pm 4 \mu \mathrm{mol} \mathrm{L}^{-1}, \mathrm{~F}_{3,72}=25.73, p<$ 0.001 ) and $250 \mu \mathrm{mol} \mathrm{L}{ }^{-1}$ for $\mathrm{NH}_{4}^{+}$(average 87 [50] $\pm 98 \mu \mathrm{mol} \mathrm{L}{ }^{-1}, \mathrm{~F}_{3,72}=26.45, p<0.001$ ) (Fig. 4). Similarly, submerged macrophytes that overwinter 
(a)

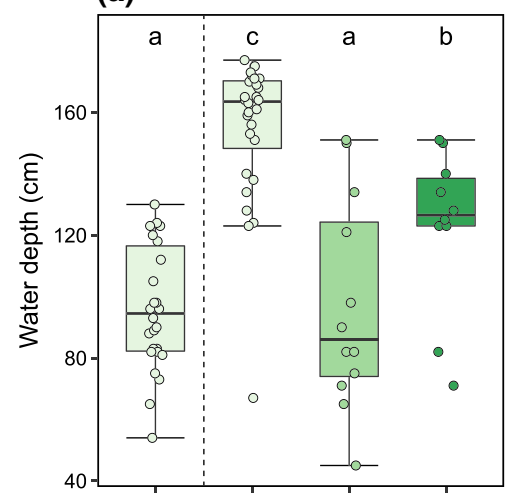

(b)

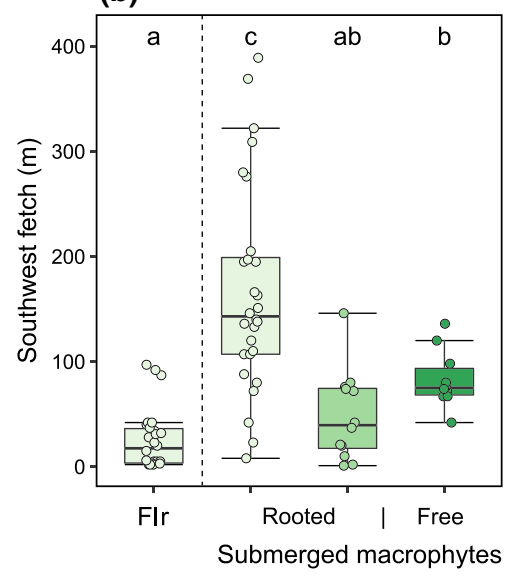

(c)

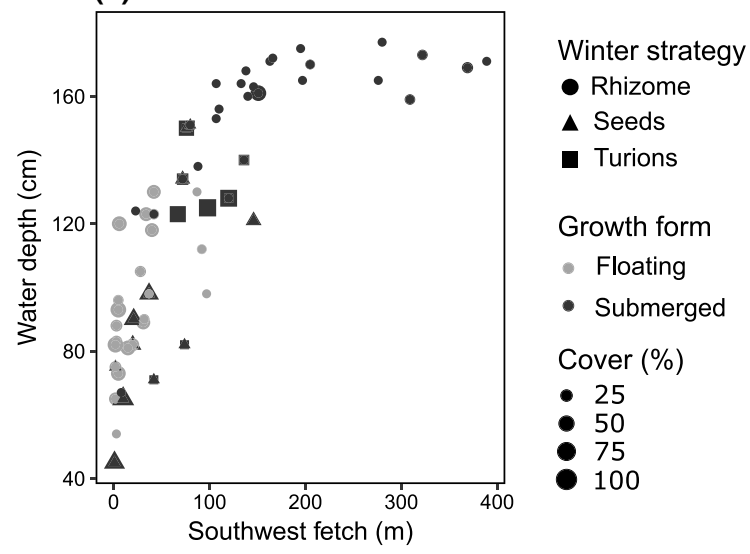

with rhizomes, occurred at low porewater $\mathrm{P}$ and $\mathrm{NH}_{4}{ }^{+}$ concentrations (average 9 [7] $\pm 5 \mu \mathrm{mol} \mathrm{P} \mathrm{L}^{-1}$, average $202[171] \pm 115 \mu \mathrm{mol} \mathrm{NH}_{4}^{+} \mathrm{L}^{-1}$ ). In contrast, submerged macrophytes that overwinter with seeds or turions occurred at higher P (average 33 [24] \pm 30 and $37[35] \pm 23 \mu \mathrm{mol} \mathrm{P} \mathrm{L}{ }^{-1}$, respectively) and $\mathrm{NH}_{4}{ }^{+}$concentrations (average $458[438] \pm 292$ and
4Fig. 3 Environmental conditions related to growth form and winter strategy. Differences between macrophyte characteristics (growth form: Flr [rooted floating-leaved ] and submerged [rooted and free-floating; free], and winter strategy: rhizome, seed or turion) and (a) water depth $(\mathrm{cm}),(\mathbf{b})$ southwestern fetch (m), (c) the relationship between water depth and south-west fetch. Color: macrophyte form. Symbol: winter strategy. Size of a symbol: vegetation cover (\%). Boxplots show the median (middle line), quartiles (boxes), 1.5 times the interquartile range (IQR) (whiskers), and the individual data values (dots). Dots outside the whiskers are extreme values. Different letters indicate significant differences (Tukey post hoc tests, $p<$ $0.05) . N=26,33,17$, and 15 for floating rhizome, submerged rhizome, submerged seed and submerged turions, respectively

538 [567] $\pm 265 \mu \mathrm{mol} \mathrm{NH}_{4}^{+} \mathrm{L}^{-1}$, respectively). Porewater K concentrations were equal for all groups with average concentrations around $100 \mu \mathrm{mol} \mathrm{K} \mathrm{L}{ }^{-1}$ (Fig. $4 \mathrm{c}, \mathrm{F}_{3,72}=1.7, p=0.2$ ).

\section{Discussion}

We studied the occurrence of rooted floating-leaved and submerged macrophytes in a shallow peat lake complex characterized by a thick and incohesive sludge substrate. We related their occurrence to growth form and life-history strategies for wintering to gain insight into the functioning of this humanmade system. Our survey demonstrates that fetch and water depth differentially affect the occurrence of macrophytes, depending on their growth forms and life-history strategies (Fig. 5). Specifically, tall caulescents (e.g., P. lucens) occurred at more exposed locations relative to small caulescents in peat lakes (e.g., C. demersum), in contrast to the general model devised by Bornette $\&$ Puijalon (2009). Therefore, we propose an adapted predictive model for the occurrence of macrophytes in shallow peat lakes as outlined below. Altogether, these results may aid in speciesselection to revegetate shallow peat lakes depending on the environmental context (e.g., exposed versus sheltered; deep versus shallow).

Occurrence of aquatic macrophytes

The occurrence of $N$. marina in the shallowest and lowest-fetch zone of the lake (40-100 cm depth, fetch $<100 \mathrm{~m}$ ) indicates that light conditions are sufficient to allow submerged macrophyte growth from seeds 
(a)

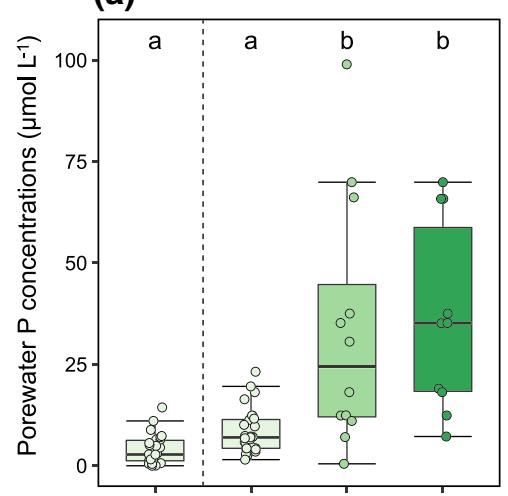

(b)

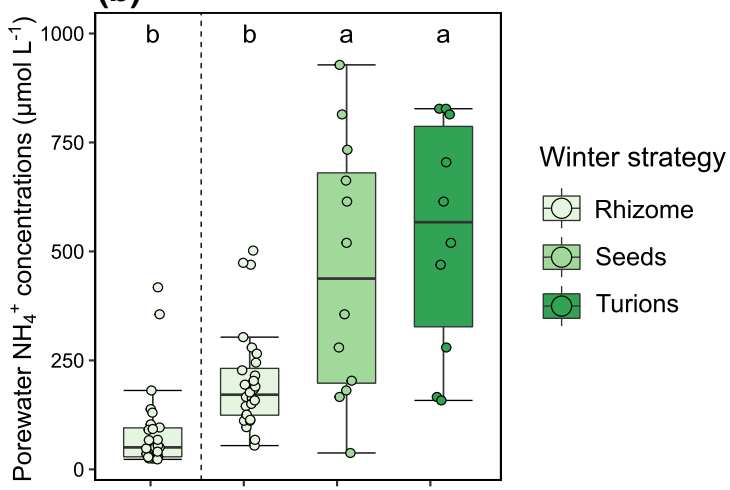

(c)

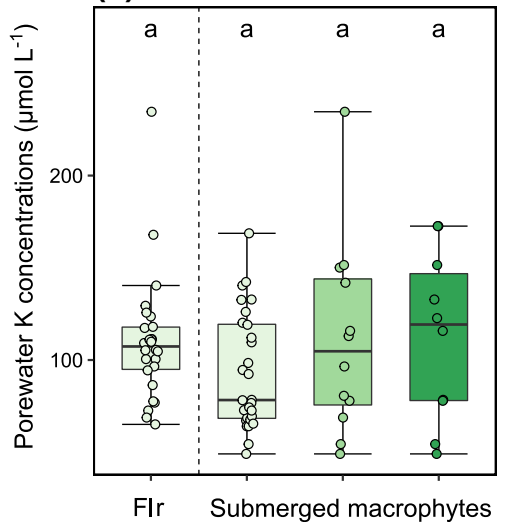

(Chambers \& Kalff, 1987). This is also supported by the 5-year average light extinction $(1.9 \mathrm{~m})$ data at this site (Dorenbosch et al., 2017). Interestingly, N. marina reached its highest cover at most-sheltered locations where fine particulate matter settles and a thick sludge layer accumulated, but where rooted floating-leaved macrophytes were absent (Supplementary Fig. S2, 3). $N$. marina is known to colonize such areas, because seedling establishment is successful on soft sediments and unsuccessful on firm sediments (Forsberg, 1965;
4Fig. 4 Porewater nutrients related to growth form and lifehistory strategies. Differences between macrophyte characteristics (growth form: Flr [rooted floating-leaved] and submerged [rooted and free-floating; free], and winter strategy: rhizome, seed or turion) and (a) porewater $\mathrm{P}$ concentrations $\left(\mu \mathrm{mol} \mathrm{L}{ }^{-1}\right)$, (b) porewater $\mathrm{NH}_{4}{ }^{+}$concentrations $\left(\mu \mathrm{mol} \mathrm{L}{ }^{-1}\right)$, and (c) porewater $\mathrm{K}$ concentrations $\left(\mu \mathrm{mol} \mathrm{L}{ }^{-1}\right)$. Boxplots show the median (middle line), quartiles (boxes), 1.5 times the interquartile range (IQR) (whiskers), and the individual data values (dots). Dots outside the whiskers are extreme values. Different letters indicate significant differences (Tukey post hoc tests, $p<$ $0.05) . N=26,33,17$, and 15 for floating rhizome, submerged rhizome, submerged seed and submerged turions, respectively

van Vierssen, 1982, Handley \& Davy, 2002). However, rooted floating-leaved rooted are not well adapted to very soft sediments, as their heavy seeds can sink to a depth that inhibits germination (BarratSegretain, 1996). Furthermore, our data show that rooted floating-leaved macrophytes occur at a water depth up to $120 \mathrm{~cm}$ depth and a southwestern fetch of $100 \mathrm{~m}$ (Fig. 3a-b, Supplementary Fig. S2), while submerged macrophytes do not occur as frequently in this zone (see e.g., submerged macrophytes with turions/rhizomes in Fig. 3a). As submerged macrophytes occur in the shallowest (seeds) and deeper parts of the lake (seed, turion, rhizomes), but not in the zone dominated by floating-rooted macrophytes, their occurrence may be driven by competition between rooted floating-leaved plants and submerged-growing plants. A possible explanation might be that rooted floating-leaved macrophytes reduce light availability for submerged vegetation. Indeed, Nuphar is known to grow dense and strongly block light (Nurminen \& Horppila, 2006; Wahl, 2008; Schoelynck et al., 2014), making them superior competitors for light that outcompete submerged-growing plants (Scheffer et al., 2003; Netten et al., 2010; Seto et al., 2013; Strange et al., 2018). Furthermore, perennial aquatic species (e.g., N. lutea, N. alba, Potamogeton sp.) are known to typically take over communities mainly consisting of seed or vegetatively-dispersed macrophytes during succession (e.g., C. demersum or $N$. marina) (Bornette \& Puijalon, 2011).

We found that in the deepest zone of the lake with largest fetch, submerged macrophytes with an extensive rhizomal network still occurred (e.g., P. lucens), while less strongly rooted or submerged free-floating plants were consistently absent (e.g., C. demersum, Fig. 3). The lack of submerged macrophytes other 


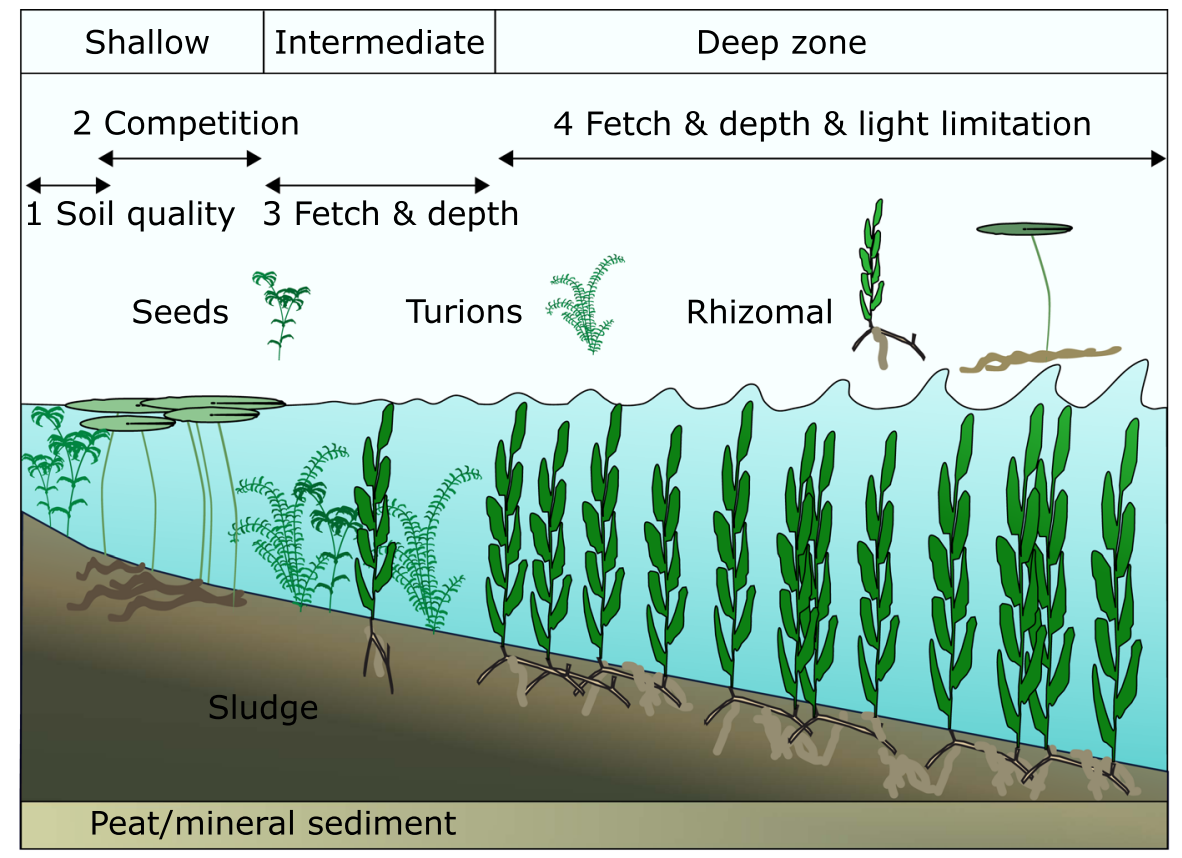

Nutrients (N-P)

\section{Fetch \& water depth}

Fig. 5 Graphical summary of the macrophyte zonation in our peat lake-system and its possible driving mechanisms. In the shallow zone, the distribution of floating and submerged vegetation may be driven by (1) sediment cohesion and seed weight, as rooted floating-leaved macrophytes may be unable to germinate in non-cohesive sediment, because their heavy seeds sink into it (Barrat-Segretain 1996), (2) when they are able to germinate, they are very strong competitors, because they shade submerged vegetation, thereby limiting their growth. Rooted floating-leaved vegetation occurrence may be limited when fetch and water depth become too great. In the intermediate zone, when rooted floating-leaved macrophytes vegetation does not occur (3) various submerged macrophyte species occur that

than strongly rooting ones can either be explained by wind-driven waves or lower availability of light. A high fetch, and thus wind-driven waves, may result in macrophyte damage, breakage or uprooting (Schutten et al., 2005). An extensive rhizomal network provides (1) strong anchoring in unstable sediment during storm events, (2) storage of energy in the rhizomes that allows a fast regrowth in spring, and (3) an advantage by forming high stands that reach the water surface, allowing them to cope with poor light conditions (Wiegleb et al., 1991; Schutten et al., 2005; van Zuidam \& Peeters, 2012). These observations differ differ in life-history strategies for overwintering. At even greater depths and fetch, (4) lower light availability at the sediment level combined with higher changes of uprooting by exposed conditions, most likely inhibits submerged vegetation developing from seeds and turions. Here, only well rooted and tallgrowing submerged plants with an extensive rhizomal network are able to cope with lower light levels, most likely because they can utilize energy stored in their rhizomes to invest in the formation of long shoots at the onset of the growing season. Symbols for diagrams courtesy of the Integration and Application Network, IAN Image Library (https://ian.umces.edu/ imagelibrary/)

from the expected distribution of major growth forms described by the conceptual model from Bornette \& Puijalon (2009). Moreover, as opposed to their model, we found that tall caulescents (e.g., P. lucens) occurred at locations with lower porewater nutrient concentrations, while small caulescents (e.g., $C$. demersum) occurred at locations with the highest porewater nutrient concentrations. Also, recent work in China, highlights that $P$. lucens can only cope with hydrodynamic stress when the surface water was not eutrophic, while $C$. demersum and $M$. spicatum were most tolerant species to both eutrophication and 
hydrodynamic stress (Zhu et al., 2018b). Taken together, we propose an adapted conceptual model for the occurrence of aquatic macrophytes in shallow peat lakes that includes growth form, life-history strategies for overwintering and several abiotic factors (Fig. 5).

Beyond traits for overwintering, $C$. demersum differs with respect to other submerged macrophytes, as it is a free-floating and non-rooted plant and does not directly absorb phosphorus form the sediment, while rooted plants do (Barko \& Smart, 1981). This might lead to lower porewater phosphorus concentrations where rooted plants occur (Wigand et al., 1997). These functional differences might be an alternative explanation for the differences in porewater nutrient concentrations between this and other groups of submerged macrophytes. Next to functional differences, aquatic plants can adapt their morphology (e.g., small and streamlined plants) depending on local hydrodynamic stress level and on whether the water is eutrophic or mesotrophic (Zhu et al., 2018a). Future research endeavors related to the occurrence of aquatic macrophytes might more explicitly consider changes in plant morphology.

\section{Implications for shallow lake restoration}

In Europe, and in the Netherlands, active revegetation programs and natural revegetation following improved water conditions of unvegetated shallow lakes is important with respect to the European Water Framework Directive (Bouleau \& Pont, 2015). This framework sets targets for the ecological quality of water bodies (e.g., composition and abundance of macrophytes). However, restoration is challenging due to various, and often human-induced, bottlenecks including eutrophication, carbon limitation, water clarity and overgrazing (Gulati \& van Donk, 2002; Lamers et al., 2002; van de Haterd \& ter Heerdt, 2007; Bakker et al., 2013; Phillips et al., 2016). This study provides insight into the occurrence of certain species in a shallow peat lake complex, without light limitation and without recreation and associated disturbances, which could be driven by growth form and life-history traits, water depth and fetch. For restoration measures, this implies that some species can only be expected within a certain fetch and water depth (e.g., N. lutea and N. alba) or that certain species should be used for restoration measures that can occur at sites with a high fetch and water depth (e.g., $P$. lucens). Beyond our survey, grazing by water birds, crayfish and fish may influence the occurrence of certain species by selective consumption (Bakker et al., 2013; Roessink et al., 2017). To improve the understanding of the functioning of shallow peat lakes, future research might focus on the interaction between grazing and the occurrence of macrophytes that have distinct life-history traits. Altogether, the improved understanding of the biogeochemical and hydromorphological functioning of this peat lake complex may aid in the revegetation and conservation of shallow peat lakes via species-selection depending on the environmental context.

Acknowledgements The authors would like to thank Roy Peters, Germa Verheggen and Sebastian Krosse for their help with chemical analyses. We thank Natuurmonumenten for site access and boat use.

Authors' contributions All authors (R.J.M.T., M.D., L.P.M.L., A.J.P.S., W.R., W.L., K.D., G.S.F., T.J.B., T.v.d.H.) contributed to the study conception and design. R.J.M.T. and T.v.d.H. conducted the fieldwork and wrote the first draft of the paper, and all authors (see list above) contributed to subsequent drafts.

Funding R.J.M.T., G.S.F., K.D. and W.L. were funded by de Nederlandse Organisatie voor Wetenschappelijk Onderzoek/ Toegepaste en Technische Wetenschappen-Open Technology Programme (NWO)/TTW-OTP grant 14424, in collaboration with the following private and public partners: Natuurmonumenten, STOWA, Rijkswaterstaat, Van Oord, Bureau Waardenburg, Enexio and Rodenburg Biopolymers. T.v.d.H. was funded by NWO/TTW-Vidi grant 16588 .

Availability of data and material All data that support the main findings of this study are available via the Data Archiving and Networked Services (DANS) EASY (https://doi.org/10. 17026/dans-xee-h224) (Temmink et al., 2021).

\section{Declarations}

Conflict of interest The authors declare that there is no conflict of interest.

Consent for publication All authors agree with the content presented in the manuscript in question.

Open Access This article is licensed under a Creative Commons Attribution 4.0 International License, which permits use, sharing, adaptation, distribution and reproduction in any medium or format, as long as you give appropriate credit to the original author(s) and the source, provide a link to the Creative Commons licence, and indicate if changes were made. The images or other third party material in this article are included in 
the article's Creative Commons licence, unless indicated otherwise in a credit line to the material. If material is not included in the article's Creative Commons licence and your intended use is not permitted by statutory regulation or exceeds the permitted use, you will need to obtain permission directly from the copyright holder. To view a copy of this licence, visit http://creativecommons.org/licenses/by/4.0/.

\section{References}

Bakker, E. S., J. M. Sarneel, R. D. Gulati, Z. Liu \& E. van Donk, 2013. Restoring macrophyte diversity in shallow temperate lakes: biotic versus abiotic constraints. Hydrobiologia 710: 23-37. https://doi.org/10.1007/s10750-012-1142-9.

Bakker, E. S., K. A. Wood, J. F. Pagès, G. F. Veen, M. J. A. Christianen, L. Santamaría, B. A. Nolet \& S. Hilt, 2016. Herbivory on freshwater and marine macrophytes: a review and perspective. Aquatic Botany 135: 18-36. https://doi. org/10.1016/j.aquabot.2016.04.008.

Barko, J. W. \& R. M. Smart, 1981. Sediment-based nutrition of submersed macrophytes. Aquatic Botany 10: 339-352. https://doi.org/10.1016/0304-3770(81)90032-2.

Barrat-Segretain, M.-H., 1996. Germination and colonisation dynamics of Nuphar lutea (L.) Sm. in a former river channel. Aquatic Botany 55: 31-38. https://doi.org/10. 1016/0304-3770(96)01062-5.

Bengtsson, L. \& T. Hellström, 1992. Wild-induced resuspension in a small shallow lake. Hydrobiologia 241: 163-172. https://doi.org/10.1007/bf00028639.

Bornette, G. \& S. Puijalon, 2009. Macrophytes: Ecology of Aquatic Plants Encyclopedia of Life Sciences (ELS). Wiley, Chichester.

Bornette, G. \& S. Puijalon, 2011. Response of aquatic plants to abiotic factors: a review. Aquatic Sciences 73: 1-14. https://doi.org/10.1007/s00027-010-0162-7.

Borst, A. C. W., W. C. E. P. Verberk, C. Angelini, J. Schotanus, J.-W. Wolters, M. J. A. Christianen, E. M. van der Zee, M. Derksen-Hooijberg \& T. van der Heide, 2018. Foundation species enhance food web complexity through non-trophic facilitation. PLOS ONE 13: https://doi.org/10.1371/ journal.pone.0199152.

Bouleau, G. \& D. Pont, 2015. Did you say reference conditions? Ecological and socio-economic perspectives on the European Water Framework Directive. Environmental Science \& Policy 47: 32-41. https://doi.org/10.1016/j.envsci.2014. 10.012 .

Chambers, P. A. \& J. Kalff, 1987. Light and nutrients in the control of aquatic plant community structure. I. situ experiments. Journal of Ecology 75: 611-619. https://doi. org/10.2307/2260193.

Dorenbosch, M., A. Bak, L. N. de Senerpont Domis, E. S. Bakker, R. Loeb, A. J. P. Smolders, R. J. M. Temmink \& T. van der Heide, 2017. Sleutelfactoren voor de groei en overleving van submerse waterplanten. Effecten van licht, perifyton, bodemstructuur en -chemie, verspreiding en graas I Key factors for the growth and survival of submerged macrophytes. Effects of light, perifyton, soil chemistry and -structure, dispersal and herbivory. Bureau Waardenburg Rapportnr. 16-174. Bureau Waardenburg, AKWA / NIOO, B-WARE en Radboud Universiteit Nijmegen.

Forsberg, C., 1965. Sterile germination of oospores of Chara and seeds of Najas marina. Physiologia Plantarum 18: 128-137. https://doi.org/10.1111/j.1399-3054.1965. tb06875.x.

Fraters, B., A. Hooijboer, G. Rijs, N. van Duijnhoven \& J. C. Rozemeijer, 2017. Waterkwaliteit in Nederland; toestand (2012-2015) en trend (1992-2015): Addendum bij rapport 2016-0076.

Gulati, R. D. \& E. van Donk, 2002. Lakes in the Netherlands, their origin, eutrophication and restoration: state-of-the-art review. Hydrobiologia 478: 73-106. https://doi.org/10. 1023/a:1021092427559.

Hammer, D. A. \& R. Bastian, 1989. Wetlands ecosystems: natural water purifiers. Constructed wetlands for wastewater treatment: municipal, industrial and agricultural 5.

Handley, R. J. \& A. J. Davy, 2002. Seedling root establishment may limit Najas marina L. to sediments of low cohesive strength. Aquatic Botany 73: 129-136. https://doi.org/10. 1016/S0304-3770(02)00015-3.

Immers, A., E. Bakker, E. Van Donk, G. Ter Heerdt, J. Geurts \& S. Declerck, 2015. Fighting internal phosphorus loading: an evaluation of the large scale application of gradual Feaddition to a shallow peat lake. Ecological Engineering 83: 78-89. https://doi.org/10.1016/j.ecoleng.2015.05.034.

Jackson, R. B., S. R. Carpenter, C. N. Dahm, D. M. McKnight, R. J. Naiman, S. L. Postel \& S. W. Running, 2001. Water in a changing world. Ecological Applications 11:1027-1045. https://doi.org/10.1890/1051-0761(2001)011\%5b1027: wiacw\%5d2.0.co;2.

Lamers, L. P. M., A. J. P. Smolders \& J. G. M. Roelofs, 2002. The restoration of fens in the Netherlands. Hydrobiologia 478: 107-130. https://doi.org/10.1023/a:1021022529475.

Lamers, L. P. M., L. L. Govers, I. C. J. M. Janssen, J. J. M. Geurts, M. E. W. Van der Welle, M. M. Van Katwijk, T. Van der Heide, J. G. M. Roelofs \& A. J. P. Smolders, 2013. Sulfide as a soil phytotoxin-a review. Frontiers in Plant Science 4: 268. https://doi.org/10.3389/fpls.2013.00268.

Lehner, B. \& P. Döll, 2004. Development and validation of a global database of lakes, reservoirs and wetlands. Journal of Hydrology 296: 1-22. https://doi.org/10.1016/j.jhydrol. 2004.03.028.

Łoboda, A., Ł. Przyborowski, M. Karpiński, R. Bialik \& V. Nikora, 2018. Biomechanical properties of aquatic plants: the effect of test conditions. Limnology and Oceanography: Methods 16: 222-236. https://doi.org/10.1002/lom3. 10239.

Murphy, K., A. Efremov, T. A. Davidson, E. Molina-Navarro, K. Fidanza, T. C. C. Betiol, P. Chambers, J. T. Grimaldo, S. V. Martins \& I. Springuel, 2019. World distribution, diversity and endemism of aquatic macrophytes. Aquatic Botany 158: https://doi.org/10.1016/j.aquabot.2019.06. 006.

National Research Council Committee, 2010. Hydrogen sulfide acute exposure guideline levels Acute exposure guideline levels for selected airborne chemicals: volume 9. National Academies Press (US). 
Netten, J. J., G. H. Arts, R. Gylstra, E. H. van Nes, M. Scheffer \& R. M. Roijackers, 2010. Effect of temperature and nutrients on the competition between free-floating Salvinia natans and submerged Elodea nuttallii in mesocosms. Fundamental and Applied Limnology 177: 125. https://doi.org/ 10.1127/1863-9135/2010/0177-0125.

Nurminen, L. \& J. Horppila, 2006. Efficiency of fish feeding on plant-attached prey: effects of inorganic turbidity and plant-mediated changes in the light environment. Limnology and Oceanography 51: 1550-1555. https://doi.org/10. 4319/10.2006.51.3.1550.

Phillips, G., N. Willby \& B. Moss, 2016. Submerged macrophyte decline in shallow lakes: what have we learnt in the last forty years? Aquatic Botany 135: 37-45. https://doi. org/10.1016/j.aquabot.2016.04.004.

R Core Team, 2020. R: A Language and Environment for Statistical Computing. R Foundation for Statistical Computing, Vienna, Austria.

Roessink, I., R. Gylstra, P. G. Heuts, B. Specken \& F. Ottburg, 2017. Impact of invasive crayfish on water quality and aquatic macrophytes in the Netherlands. Aquatic Invasions. https://doi.org/10.3391/ai.2017.12.3.12.

Scheffer, M., 1997. Ecology of Shallow Lakes, Vol. 22. Springer, New York.

Scheffer, M., S. Carpenter, J. A. Foley, C. Folke \& B. Walker, 2001. Catastrophic shifts in ecosystems. Nature 413: 591-596. https://doi.org/10.1038/35098000.

Scheffer, M., S. Szabó, A. Gragnani, E. H. van Nes, S. Rinaldi, N. Kautsky, J. Norberg, R. M. M. Roijackers \& R. J. M. Franken, 2003. Floating plant dominance as a stable state. Proceedings of the National Academy of Sciences 100: 4040-4045. https://doi.org/10.1073/pnas.0737918100.

Schoelynck, J., K. Bal, V. Verschoren, E. Penning, E. Struyf, T. Bouma, D. Meire, P. Meire \& S. Temmerman, 2014. Different morphology of Nuphar lutea in two contrasting aquatic environments and its effect on ecosystem engineering. Earth Surface Processes and Landforms 39: 2100-2108. https://doi.org/10.1002/esp.3607.

Schutten, J., J. Dainty \& A. J. Davy, 2005. Root anchorage and its significance for submerged plants in shallow lakes. Journal of Ecology 93: 556-571. https://doi.org/10.1111/j. 1365-2745.2005.00980.X.

Seto, M., N. Takamura \& Y. Iwasa, 2013. Individual and combined suppressive effects of submerged and floatingleaved macrophytes on algal blooms. Journal of Theoretical Biology 319: 122-133. https://doi.org/10.1016/j.jtbi. 2012.11.016.

Smolders, A. J. P., L. P. M. Lamers, E. Lucassen, G. Van der Velde \& J. G. M. Roelofs, 2006. Internal eutrophication: how it works and what to do about it-a review. Chemistry and Ecology 22: 93-111. https://doi.org/10.1080/ 02757540600579730.

Søndergaard, M., J. P. Jensen \& E. Jeppesen, 2003. Role of sediment and internal loading of phosphorus in shallow lakes. Hydrobiologia 506: 135-145. https://doi.org/10. 1023/B:HYDR.0000008611.12704.dd.

Song, X., Z. Wang, B. Xiao, E. Li \& X. Wang, 2017. Growth of Potamogeton crispus L. from turions in darkness: Implications for restoring submerged plants in eutrophic lakes. Ecological Engineering 101: 255-260. https://doi.org/10. 1016/j.ecoleng.2017.01.035.
Strange, E., J. Hill \& J. Coetzee, 2018. Evidence for a new regime shift between floating and submerged invasive plant dominance in South Africa. Hydrobiologia 817: 349-362. https://doi.org/10.1007/s10750-018-3506-2.

Temmink, RJM., Dorenbosch, M., Lamers, LPM., Smolders, AJP., Rip, W., Lengkeek, W., Didderen, K., Fivash, GS., Bouma, TJ. \& van der Heide, T. 2021. Data from: Growth forms and life-history strategies predict the occurrence of aquatic macrophytes in relation to environmental factors in a shallow peat lake complex, DANS, https://doi.org/10. 17026/dans-xee-h224.

van Bergen, T. J. H. M., R. J. M. Temmink, L. van Tweel-Groot, W. J. Bakker, K. Rehlmeyer, A. H. W. Koks, A. C. Waajen, J. G. M. Roelofs, A. P. Grootjans, T. van der Heide \& L. P. M. Lamers, 2020. Self-facilitation and negative species interactions could drive microscale vegetation mosaic in a floating fen. Journal of Vegetation Science 31: 343-354. https://doi.org/10.1111/jvs.12851.

van de Haterd, R. J. W. \& G. N. J. ter Heerdt, 2007. Potential for the development of submerged macrophytes in eutrophicated shallow peaty lakes after restoration measures. Hydrobiologia 584: 277-290. https://doi.org/10.1007/ s10750-007-0593-x.

van Vierssen, W., 1982. Some notes on the germination of seeds of Najas marina L. Aquatic Botany 12: 201-203. https:// doi.org/10.1016/0304-3770(82)90015-8.

van Zuidam, J. P. \& E. T. H. M. Peeters, 2012. Cutting affects growth of Potamogeton lucens L. and Potamogeton compressus L. Aquatic Botany 100: 51-55. https://doi.org/10. 1016/j.aquabot.2012.02.005.

Verhofstad, M. J. J. M., M. M. Alirangues Núñez, E. P. Reichman, E. van Donk, L. P. M. Lamers \& E. S. Bakker, 2017. Mass development of monospecific submerged macrophyte vegetation after the restoration of shallow lakes: roles of light, sediment nutrient levels, and propagule density. Aquatic Botany 141: 29-38. https://doi.org/10. 1016/j.aquabot.2017.04.004.

Wahl, M., 2008. Ecological modulation of environmental stress: interactions between ultraviolet radiation, epibiotic snail embryos, plants and herbivores. Journal of Animal Ecology 1: 549-557. https://doi.org/10.1111/j.1365-2656.2007. 01352.x.

Wiegleb, G., H. Brux \& W. Herr, 1991. Human impact on the ecological performance of Potamogeton species in northwestern Germany. Vegetatio 97: 161-172. https://doi.org/ $10.1007 / \mathrm{bf} 00035389$.

Wigand, C., J. C. Stevenson \& J. C. Cornwell, 1997. Effects of different submersed macrophytes on sediment biogeochemistry. Aquatic Botany 56: 233-244. https://doi.org/10. 1016/S0304-3770(96)01108-4.

Zeeuw, J Wd, 1978. Peat and the Dutch Golden Age. The historical meaning of energy-attainability. AAG Bijdragen 21: 3-31.

Zhu, G., G. Di, M. Zhang, T. Cao, L. Ni, R. Fang \& G. Yu, 2018a. Biomechanical response of a submerged, rosetteforming macrophyte to wave action in a eutrophic lake on the Yungui Plateau, China. Environmental Science and Pollution Research 25: 34027-34045. https://doi.org/10. 1007/s11356-018-3047-2.

Zhu, G., C. Yuan, G. Di, M. Zhang, L. Ni, T. Cao, R. Fang \& G. $\mathrm{Wu}, 2018 \mathrm{~b}$. Morphological and biomechanical response to 
eutrophication and hydrodynamic stresses. Science of the Total Environment 622: 421-435. https://doi.org/10.1016/ j.scitotenv.2017.11.322.
Publisher's Note Springer Nature remains neutral with regard to jurisdictional claims in published maps and institutional affiliations. 